The International J ournal of the First Year in Higher

Education

ISSN: 1838-2959

Volume 5, Issue 2, pp. 1-20

August 2014

Feature-keynote presentation

\title{
The First Year in Higher Education - Where to from here?
}

Karen Nelson

Pro Vice-Chancellor (Students), University of the Sunshine Coast, Sippy Downs, Australia

\section{Summary}

Professor Karen Nelson delivered her keynote presentation The First Year in Higher Education - Where to from here? at the 17th International First Year in Higher Education Conference in Darwin, Australia on the $8^{\text {th }}$ of July, 2014. Acknowledging the significant body of work and good practice (both research and scholarship) in the sector, the keynote proposes a way forward in FYHE: A broader concept of student success requiring a similar amount of scholarship and responsiveness as has been committed to the FYHE.

The keynote is reproduced in article form by the author and John Clarke (Editor) for the journal issue.

Slides mentioned in this paper can be viewed on pages 18-20. The full set of PowerPoint slides from the presentation can be found at http://fyhe.com.au/past papers/papers14/keynote2.pdf

\section{Please cite this article as:}

Nelson, K. (2014). Keynote: The First Year in Higher Education - Where to from here? The International Journal of the First Year in Higher Education, 5(2), 1-20. doi: 10.5204/intjfyhe.v5i2.243

This article has been peer reviewed and accepted for publication in Int J FYHE. Please see the Editorial Policies under the 'About' section of the Journal website for further information.

(C) Copyright of articles is retained by author/s. As an open access journal, articles are free to use, with proper attribution, in educational and other non-commercial settings. ISSN: 1838-2959 


\section{Biography}

Professor Karen Nelson is the Pro ViceChancellor (Students) at the University of the Sunshine Coast (USC). Prior to joining USC in April 2014 she was Director, Student Success and Retention at the Queensland University of Technology (QUT) and prior to that from 2008, she was the QUT Director, First Year Experience. Karen's PhD is in organisational information and knowledge management and she has held a number of traditional academic roles in her discipline including designing, coordinating and teaching subjects and programs at undergraduate and postgraduate levels. She has supervised twelve higher degree research students to completion. Karen's research focuses topics of relevance to student engagement in higher education, the first year experience and institutional information and knowledge management practices of relevance to these topics. She has led a series of national learning and teaching research projects and presents and consults nationally and internationally in these areas.

Karen's current research focuses on developing a Maturity Model for Student Engagement, Success, and Retention (http://studentengagementmaturitymodel. net/), and disseminating the outcomes of her recently completed project Safeguarding Student Learning (https://safeguardingstudentlear ning.net/). Karen was also a partner in a third project Effective Teaching and Support of Students from Low Socioeconomic Backgrounds (http://www.lowses.edu.au/) and is involved in disseminating that work with project team members.

Karen chaired the International First Year in Higher Education Conference organising committee from 2009-2013 and is the founding Editor-in-Chief of the
International Journal of the First Year in Higher Education and the Co-convenor of the FYHE virtual centre (all accessible from http://fyhe.com.au). She is a member of the Editorial Board of Active Learning in Higher Education Journal. Her contributions to higher education have been recognised by more than ten national and institutional awards, including a Vice-Chancellors Award for Excellence and three Australian Awards for University Teaching.

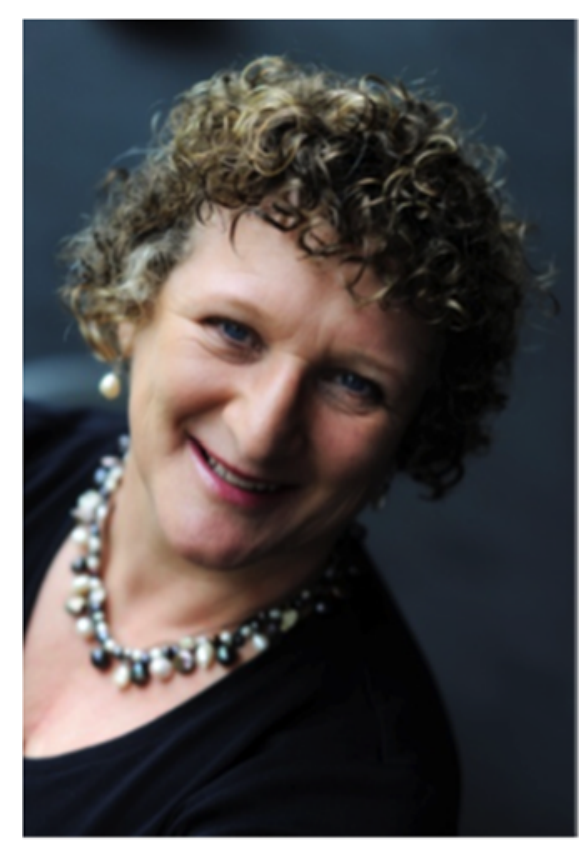

Karen Nelson 
The First Year in Higher Education - Where to from here?

\section{Abstract}

Attention to the first year in higher education (FYHE) has been a priority for academic and professional educators for forty years or more. In the Australasian higher education sectors, our practical, empirical and theoretical knowledge about the FYHE has developed steadily over two decades. During this time, and in scholarly ways, we have collectively learnt and built on what has gone before. The range of programs and practices that enhance the FYHE has gradually matured to where it is now, and there is a large body of evidence about what works. We know that high-impact and sustainable FYHE programs and practices are best designed and enacted within curricula that engage, challenge and support first year learners. Ideally, these programs arise from the collaborative efforts of discipline-based academic staff and specialist educators. Not only have we come to understand what good practice in the FYHE looks like, but also that such good practice benefits all commencing students, irrespective of their backgrounds and preparedness for high education. As a result, the cohorts for whom this attention to the FYHE has had critical importance now achieve outcomes equivalent to those of their peers for whom higher education was always an accessible and viable option.

Nevertheless, serious challenges remain, and the benefits foreshadowed by the promise of higher education are not enjoyed by many of the students who commence in our institutions. Although we know that a successful transition to higher education provides the foundation for what follows, more focused attention on the role played by institutions in engendering student success, not just in their first year, but throughout their enrolment, is required. This keynote address plots the recent history of the Australasian FYHE and proposes, as a way forward, a broader concept that addresses student success and requires the same degree of scholarship and attention as has been dedicated to the FYHE.

\section{Introduction}

In this paper, I reflect on the issues, problems and challenges that have drawn us together at this conference and which will continue to do so into the future. The key issue or challenge is in the promise of a higher education (HE) and the life-long financial and social benefits it brings to individuals and more broadly delivers to communities, civil society and to a knowledge economy. In the context of who benefits from higher education, recently there has been a lot of discussion, nationally and internationally about the costs of higher education and the relative contributions of the private and public purse. In Australia, not all of that conversation has been balanced or complete in its assessment, nor in my opinion does it draw well on the lessons learned from other large HE systems, such as the United States (see for example recent commentary on inequality by Nobel Laureate Joseph Stigliz e.g. Greber, 2014; Stigliz, 2014 at 48:20 minutes). That particular topic is a key concern to many of us gathered here and although I will touch in the issue of affordability briefly, it is worthy of a much more rigorous public debate than I have the time to explore here. However, to discuss where we have been in advancing the FYHE and how we may further enhance our efforts, I will cover five topics. They are:

- the problem, issues and challenges that require attention to the FYHE; 
- how we have responded to these challenges;

- what we know and have learnt along the way;

- how we can build on what we have learnt works; and

- a broader foundation for future action

\section{The problem, issues and challenges}

Denise Bradley and her colleagues (Bradley, Noonan, Nugent, \& Scales, 2008) provided an elegant expression of the role of $\mathrm{HE}$, and put it on the public record, when they stated that "higher education can transform the lives of individuals and through them their communities and the nation by engendering a love of learning for its own sake and a passion for intellectual discovery" (p. 5). More recently, Universities Australia, in their 2013 policy framework, reiterated a commitment to opportunity, equity and participation in HE (Universities Australia, 2013). These statements encapsulate both the promise and the challenges we face in realising it. Unfortunately, for many of the students who enrol in our institutions, the promised benefits are not realised. Many students leave before they even really get started, and most of the students who leave, do so in the crucial first weeks and months. These students certainly do not have the opportunity to fulfil their hopes and dreams, and unless they return to HE at another place or time, what they often leave with is a debt and no qualification.

The adjusted attrition data available (for domestic students) https://docs.education.gov.au/node/3386 $\underline{3}$ provides some indication of the movement of students between institutions. However, the details are lacking and the research literature is largely silent on this. There does not appear to be national or international analyses of the rate or impact of returning students. I'd like to draw on three types of data as ways of understanding the problem.

Firstly, data that describes our students, who they are and where they come from. Of note here are the total number of students in Australian HE institutions (1.17million), the proportion of commencing students (40\%), their age bands $(76.5 \%$ are older than 20 years of age) and the underrepresentation of students from some groups, notably students with a disability and students from remote areas. Of particular concern is the underrepresentation of students from Aboriginal and Torres Strait Islander (ATSI) backgrounds. Critical Race Theorydescribed so well by our opening keynote speaker, Professor Steve Larkin-provides a framework for action that will enhance the university experience of Australia's first nation peoples and as a result will provide for a better and fairer HE system for all.

Secondly, data that summarises the attrition rates of commencing students. The first chart (slide 7) summarises the attrition rates for 'commencing students' by State with the national average shown in black. This data is based on information about students who commenced university any time during the calendar year (Year $\mathrm{n}$ ) but are not present at the first census date in the following calendar year (Year $n+1$ ). Fortunately, the overall trend is downward. This is most evident in the Victorian data, but also apparent in the Western Australian, Australian Capital Territory and New South Wales figures. However, these summary level charts mask the individual patterns of institutional attrition, which are critical to understand. I have provided (slide 8 , which is very busy) to emphasise that comparing 
attrition rates between or among institutions is of very little value in terms of measuring the impact of work on the FYE. My view is that institutions should avoid benchmarking attrition or retention as measures of the success of their FYHE strategies and rather should seek to understand their particular institutional patterns and the variation from this pattern within their institutions and aim to achieve a downward trend in their institutional attrition rate. As we know, downwards trends within an institution can be achieved by persistently and incrementally focusing on units of study and whole of course (program) approaches and by focusing on achieving parity of outcomes between those students whom, as Tinto (2006) says have been under-served in their prior-touniversity life, compared with their betterserved and -resourced peers.

The third way of understanding the problem is to focus on data about the affordability of going to university. Proponents of uncapped places and deregulated Australian HE system argue that fee rises will not affect demand for places (Norton, 2013, p. 14). However, further increases in the ratio of private to public expenditure is likely to impact not only on the affordability of a university degree-especially for students from economically disadvantaged backgrounds-but also critically on the amount of time it takes to repay the debt that arises from the cost of a degree (Hurst, 2014; Pitman, Phillimore, \& Koshy, 2014; see also Coughlan, 2010 for a related conversation about fee rises in the UK). As shown in (slide 9), the average amount Australian students contribute to the total cost of their education is already among the highest in the world and government contribution is one of the lowest in the Organisation for Economic Cooperation and Development (OECD). The percentage ratio of public to private expenditure in 2010 was 46.5:53.5 with household, that is, individual contributions, comprising nearly three quarters $(73 \%)$ of the private contribution. By comparison, in 2010, the OECD average percentage ratio of public to private expenditure was approximately 68:32 (OECD, 2013). In the post-2014 Australian budget world, the proportion of student to government contribution will shift further towards students and student fees will rise (see slide 12). Universities, seeking to continue to provide high quality learning experiences, will increase student contributions made through the Higher Education Contribution Scheme (HECS) to compensate for the reduction in public funding available to them through the Commonwealth Grant Scheme (CGS). The Australian Education Minister, Christopher Pyne has persistently argued that fee increases will not impact on the affordability of a higher education because students are not required to pay any fees up front (e.g., Pyne, 2014, May 13). However, modelling conducted by staff at the National Centre for Student Equity in Higher Education and at Curtin University has shown that the time to repay a total deferred debt of $\$ 75,000$ is 16 years once the threshold salary is met (Pitman et al., 2014). Many students already take longer than the programed number of years to complete their degrees because they study at fractional full-time rates to be able to combine work and study. These students and those, particularly women, who have time off during their program of study for child bearing, to meet caring responsibilities, and to work to live, will pay disproportionally more for their student loans over time, because the amount they contribute, the rate of interest they pay on that loan and the length of the loan period will all increase if the changes to HE sector proposed by the Australian Government in the recent budget (Australian Government, 
2014) pass into legislation. I hope sanity emerges as a dominant theme as the debate of these changes develops.

Poverty is still one of the major reasons that students leave HE. The 2012 Centre for the Study of Higher Education (CSHE) study of student finances for Universities Australia (Bexley, Daroesman, Arkoudis, \& James, 2013) contains some concerning data. It found that $66 \%$ reported being worried about their financial situation, which rose to $75 \%$ and $80 \%$ respectively for students from low socio-economic backgrounds and ATSI students. Further the study reported that $66 \%$ of full-time students had an income less than $A \$ 20,000$ per year (well below the poverty line), and that $18.2 \%$ of students went without food and other basic necessities, which increased to more than $25 \%$ for those who were regularly worried about their financial situation. Critically, the study revealed that $50 \%$ of undergraduates rely on some financial support from family, further emphasising the challenges faced by students who from socially and economically disadvantaged backgrounds.

Empirical reports (e.g., Kift, 2009; Krause, Hartley, James, \& McInnis, 2005; Scott 2006; Yorke \& Longdon, 2008) also provide useful and informing data about the other issues that lead to students leaving. Slide 11 summarises the issues into three main categories: administrative issues, academic matters and finally personal or individual matters. The other is poverty, which we have already discussed, so I will briefly mention each of the others.

Firstly administrative matters, in particular lumpy and unclear processes that take time and attention away from learning. Often these are processes designed primarily for institutional efficiency, for what suits us rather than what will work for students.
Another important group of issues are academic matters. Two of the most widely reported issues in this category are course choice and feedback on assessment. For example, in The Student and Staff Expectations and Experiences (SSEE) Project (Brinkworth et al., 2013)-a collaboration between the University of South Australia, Flinders University and the University of Adelaide (see http://fyhe.com.au/expectations/D-1/3 of the more than 16,000 students who responded to the survey reported they had changed degrees. In terms of assessment, this project also found that while $98 \%$ of students expected feedback on their assessment items, only 55\% actually received it. The final category of personal and individual issues is often irritatingly used as an excuse to explain "good attrition" or the "things that are out of our control." I'm not Pollyanna about this, and having recently acquired student grievances and misconduct as part of my new role, I have had an intensive introduction to some of the more complex, challenging and profoundly difficult circumstances of our students that many of you know so well. Nevertheless, there are a range of issues here that we can attend to for the majority of students in order to minimise the likelihood that personal issues will lead inevitably to students having to withdraw completely. When asked, students also understand the issues that contribute to successful transition to university. Bowles and colleagues (Bowles, Fisher, McPhail, Rosenstreich, \& Dobson, 2014) identified seven different student perceptions of transition issues (see Slide 12).

It is also worth a moment just to reflect on the domain of interest for the FYHE. As we have seen from the data describing students, it is not as simple as it might seem 
at first glance. The FYE is a very personal experience, characterised by various patterns of student engagement, different cohorts, pathways, joint awards, double degrees, curricular and co-curricular responsibilities and so on. One useful way has been to define the component parts of student, curriculum and experience as shown by the example in slide 17 so that there is a shared understanding within each institution about which specific aspects are the focus of particular activities.

Finally, we have the challenge of knowing what good first year teaching looks like, and that is certainly not pedagogy according to Sheldon Cooper in his speech to undergraduate students (the character in the television series 'The Big Bang Theory' [see

https://www.youtube.com/watch?v=mpX Q8m tmbs])

\section{How we have responded to these challenges}

I will draw on two key reviews of the FYHE to summarise how we have responded to these challenges. The first is a metaanalysis of the 398 Australasian empirical reports and conceptual papers produced during the first decade of this century (Nelson, Clarke, Kift, \& Creagh, 2011). Many of the works examined were authored by delegates past and present of this conference and also reproduced in Nelson and Clarke (2014). The second is a review of ALTC/OLT funded work related to the FYHE by Trevor Gale and Stephen Parker (Gale \& Parker, 2011, 2014). We will only have time to skim the surface of these today so I will focus on some key points.

The meta-analysis divided the decade into three periods (2000-2003, 2004-2007 and 2008-2010) and examined the works in each period through two lenses of the generational approach-first mooted by Keithia Wilson and explored by Sally Kift. See Kift, Nelson and Clarke (2010) for a brief history and summary- and the first year curriculum principles (Kift, 2009). Many of you will be familiar with these concepts. In the first period, between 2000 and 2003, the focus was generally on some good work in the co-curricular space while the focus of investigations was on the influence of individual and personal characteristics on transition success. By the mid-2000s, the focus was on building capacity and practice and shifted to be more concerned with the curriculum-usually at a subject level-but the design aspects were intentional and good practice in assessment was seen as a priority. The importance of academic-professional and crossinstitution collaboration was by now apparent. In the third period, as the end of the decade approached, there was a substantial increase in the number of reports with the activities being reported largely driven by changes in national policy frameworks. There was increased rigour in the research and some key new data-driven and people-rich initiatives for early intervention as a preventative strategy emerged.

The second set of observations have their origin in Gale and Parker's Good Practice Report about work addressing student transition into HE (Gale \& Parker, 2011) which was later extended by drawing on sociological and education theory and reported in Studies in Higher Education (Gale \& Parker, 2014). Although not timebased as in the meta-analysis, the three conceptions that emerged in Gale and Parker's work reflect the observations in the earlier work: Firstly, supporting transition through "intensive" or boot camp programs; secondly, managing transition as part of the learning process or as characterised here, stages of life; and 
thirdly, understanding transition as "becoming" student driven but facilitated by a new level of maturity-the development of individual identity-in understanding FYE theory and practice.

So we have responded well. We have developed what have become tried and tested practices and we have become more mature over time in our theorising about how to respond to the issues and challenges. But what have we learnt?

\section{What we know and what we have learnt along the way}

To illustrate what we have learnt, I will draw attention to the major theoretical and empirical work that I believe encapsulate our learnings and then present some lessons learnt from our experiences.

Three frameworks that have been used to enhance practice:

Firstly, focusing on what we have learnt and now know about curriculum. I mentioned earlier the concept of a Transition Pedagogy (Kift \& Nelson, 2005) and the set of six curriculum principles (Kift, 2009) that underpin it. These principles and the Transition Pedagogy have been extremely influential as a foundation for many first year curriculum reform projects. Reflecting her role as the inaugural FYHE Fellow, Sally Kift has been more than generous in her leadership with her work and presentations on the principles to almost every Australian university and beyond in Aotearoa/New Zealand, the United Kingdom, the United States, and in Europe. As a result, the widespread use of the first year Curriculum Principles at subject, program and institutional level is well reported. As one of a myriad of international examples, see Crehan, 2014). As a framework for wholeof-institution first year curricula reform, the principles have been taken up by a number of universities including where I used to work, the Queensland University of Technology (Nelson, Smith \& Clarke, 2012), James Cook University and in large projects at Flinders University (2013), University of Technology Sydney (2014), University of Wollongong, Victoria University (2012), Edith Cowan University (n.d.) and the University of Newcastle to name a few. And, of course, they will underpin and inform our renewed focus on first year curriculum at the University of the Sunshine Coast.

Secondly, focusing on what we know about the factors that are critical for student success. Alf Lizzio and Keithia Wilson's Five Senses of Success model (Lizzio, 2006; Lizzio \& Wilson, 2004) draws attention to those critical senses of connectedness, capability, resourcefulness, purpose and culture. This model was developed and refined empirically and the model arising from this work is a valuable and elegant way of understanding what we know about student needs. Slide 22 shows the model reinterpreted by RMIT University (n.d.) in their TITO (Transitions-In Transitions-Out) project as five senses of successful transition.

Thirdly, focusing on what we know about the institutional conditions for student success. Vincent Tinto, who addressed this Conference last year, proposed four conditions for student success (Tinto, 2012). Tinto's favourite mantras for some time now have been "access without support is not opportunity" and "set clear and high expectations for your students" and both these themes are reflected in this model. Tinto's four conditions for provide a useful and parsimonious focus for institutional attention to the FYE. If all commencing students experienced these conditions I am sure we would say that we were doing particularly well. Slide 21 
illustrates the four conditions: Harnessing the classroom (virtual and physical) as the site for FYE endeavours and initiatives; using assessment as a vehicle for student learning and for informing staff about how their students are learning; and reflecting both the Kift and Lizzio models by focusing on getting the social context right so that students can interact with their peers and with staff to enhance their sense of belonging. The forth institutional condition focuses on how we communicate and set out our expectations for students in terms of their learning. To illustrate the important of setting clear expectations let's hear from Kevin. ${ }^{1}$

Keeping on this theme of expectations and experience of our students, I would like now to return to one of the major pieces of empirical work about the first year experience in the Australasian HE Sector. The SSEE Project (Brinkworth et al., 2013) collected data from more than 16,000 students and contains a wealth of knowledge about our students and their experiences. Looking at some of these findings, I am sure you will agree that despite our good intentions, best efforts and dedication to improving the FYHE, some of these findings are very concerning. In terms of creating those optimal conditions envisioned by Tinto, it seems that we still have a long way to go.

I propose that this problem may reflect that we have focused more on improving our provision of learning and teaching and support to students - that is the practices required for enhancing the FYE-and less on ensuring that policy frameworks are in place to drive institutional alignment for enhancing the FYHE. Further, our capacity to capture good practice-practices that work-and to refine our institutional processes and policy frameworks based on the evidence of the impact of these good practices requires further attention. I will return to this theme of institutional framing towards the end of this paper.

So far, we have looked at what we know in terms of theoretical frames and empirical evidence. The theoretical frameworks include: In curriculum (Transition Pedagogy, Curriculum Principles); critical personal factors (Five Senses of Success); institutional factors (Institutional conditions for success; including expectations). These robust theoretical frameworks are based on empirical evidence and have been applied in practice. We are fortunate to have a large evidence base emanating from Australasia: From Aotearoa (New Zealand), see reviews by Zepke and Leach (2010) and Zepke et al. (2005); and from Australia, see not only the afore-mentioned SSEE Project (Brinkworth et al., 2013 ) and comprehensive review (Nelson et al., 2011) but also the important and insightful quinquennial FYE reports originating from the CSHE and providing longitudinal trend data from 1995 to 2010-1995 (McInnis, James, \& McNaught, 1995), 2000 (McInnis, James, \& Hartley, 2000), 2005 (Krause, Hartley, James, \& McInnis, 2005) and 2010 (James, Krause, \& Jennings, 2010); all cited in Nelson et al. (2011).

From this extensive foundation, I would like to drill down now to four lessons for the FYE that have emerged from this discussion.

Lesson \#1: Focus on curriculum design, assessment, pedagogies and teaching practices that engage students in learning.

\footnotetext{
${ }^{1}$ At this point a video illustrating the mismatch between the promotion of university as "exciting and fun" and the reality of university assessment was shown (The video is part of the Project Unknown series http://www.projectu.com.au/coolstuff/ProjectUnknown.jsp)
} 
There are a variety of questions we might ask in terms of the role of curriculum. Who will be involved in the design and enactment of curricula? How will students come to understand their discipline and to see themselves in that discipline? What mechanisms will be in place to support students during their transition to learning at university? How will we know which students are facing the greatest challenges? The evidence presented in the frameworks I have just presented and in the two reviews of the FYHE canvassed earlier provide the answers to these questions.

Lesson \#2: Proactively monitor students' engagement in learning and make timely interventions to normalise concerns, raise confidence and promote help seeking behaviours. These programs are the most effective when the interventions are highly individualised, purposeful and delivered by experienced well-trained peers. Local best practice examples are the Auckland University of Technology's First Year Experience Program (Carlson, Scarborough, \& Carlson, 2009), the University of New England's Early Alert Program (Herrick, 2011) and the Queensland University of Technology's Student Success Program (Nelson, Duncan \& Clarke, 2009). A typical program is illustrated on slide 32 . We know that monitoring and intervention must be aligned with key milestones in the experience of FY (and other students) and importantly that the interventions need to be relevant and tailored to meet the needs of each individual student, and not about institutional efficiencies. The illustration and these programs raise the spectre of learning analytics, and that is the subject of the next lesson. Nevertheless, the positive impact on students demonstrated by these types of programs is irrefutable (e.g., Nelson, Quinn, Marrington, \& Clarke, 2012). Not only have they been shown to reduce the number of students that leave; the evidence also suggests that they enhance students' levels of engagement, most likely by increasing confidence as learners and by activating their participation in their learning. This is a current research focus that I am investigating with colleagues.

Lesson \#3 Is more of a call for the judicious use of big data-which is commonly referred to as learning analytics-and its use in HE. We need to consider the purpose of learning analytics and for whom it is designed to benefit. On this matter, the ideas provided by Greller and Drachsler (2012) and by Powell and MacNeil (2012) are worth serious consideration as we embark on projects in this domain.

Lesson \#4 We need to move away from thinking about life and learning support as being adjunct to the curricula content and think about support for learning as an integral part of programs of study. There will always be a need for individual students to have intensive learning support delivered in a 1:1 manner by professional educators. However, for a variety of different and complex reasons, most students will not participate in learning support that is provided by staff in a cocurricular way or provided in ways that are not contextualised and relevant to their program of study. Therefore, as promoted by the notion of the transition pedagogy we need to continue to build support for learning into the curricular experiences.

Of course these lessons are not definitive but they represent the main themes in the recent history of the FYHE I am canvassing in this paper. However, it seems that to fulfil the aspirations of new generations of commencing students and to meet the expectations of our communities and institutions, we will need to consider more holistic, future-focused and sophisticated approaches to our research and practice.

10| The International J ournal of the First Year in Higher Education, 5(2) August, 2014 
These approaches will need to attend to the complexity of our institutions and the sociopolitical contexts in which they are situated. Importantly, these approaches will need to attend to the complex reality of the lives of contemporary students, their hopes and aspirations and the promises of a university education.

In the next part of this paper, I will focus on how to build on what is already known. Or as Tinto (2008) puts it - how to "stop tinkering around the edges" (para 15).

\section{How we can build on what we have learnt works}

Very reasonably, you may be asking: But what does this all look like in practice? One idea situates practice on robust and extensive institutional partnerships, builds a foundation for learning by focusing on that sense of belonging, ensures that support for learning is built in and importantly focuses attention on three key curricular imperatives, the FYE, building identity through relevant learning opportunities and bringing this together for our graduating students through meaningful capstone experiences.

To build on these successes and to ensure that student achievement is put at the centre of action, we need an ethical foundation based on the principles of social justice. We recently developed a social justice framework for HE (Nelson \& Creagh, 2013) in conjunction with colleagues from ten Australasian institutions and it has the potential to be interpreted and applied across the broad range of initiatives essential for creating a environment that focuses on success. Keeping with the social justice theme, we have the notion of sociocultural incongruence that rejects the deficit notions. Based on the conceptual framework that arose from the empirical and theoretical data examined for a related OLT-funded project, practical advice for institutional leaders and educators was provided (Devlin, 2011).

We have to become more strategic in thinking about the institutional impact of initiatives designed to improve the student experience and to foster their success. One of the ways of doing this is to quantify the cost of attrition and therefore the financial benefits of reducing the rates of attrition.

So, this more sophisticated holistic approach sounds rather simple - be ethical, focus on the big picture, and ensure you build a case that is based on the financial as well as social impact of your endeavours. But no, of course it is not so simple. In the final part of this paper, I propose a broader foundation for action.

\section{A broader foundation for future action}

As a starting principle, I believe we need to be explicit about the factors that lead to success not just as advocates for students, but as champions of the student experience within our institutions. Our endeavours should not be based on what we would like to do, or have been doing, or are comfortable doing. They must be based on the evidence of what works. Critically, we need to suspend our own beliefs about what success at university looks like and attend to what success means to students.

In terms of a more holistic approach, I believe the notion of student engagement has much to offer. Studies on engagement also suggest that engagement enhances the acquisition of critical thinking, problem solving skills and enhances communication skills. Importantly in the context of striving for social inclusion in $\mathrm{HE}$, engagement is said to have a compensatory effect for 
students who come from socially, financially and culturally disadvantaged backgrounds. We have written about engagement from the perspective of the transition pedagogy (Nelson, Kift \& Clarke, 2012) because there is now evidence that engagement is critical to a successful first year experience and a good first year experience is essential for student engagement. keynotes to this conference last year, touched on both those themes. We (Nelson, Kift \& Clarke, 2012) have tried to understand engagement as a typical inputprocess-output model, an adaptation of Biggs' Presage-Process-Product (3P) Model Biggs, 1999) which pays attention to the individual and contextual factors of students and staff, as well as curricular and institutional factors that influence students'

\section{Individual and Institutional Characteristics Influencing Student Retention and Engagement (IICISRE)}

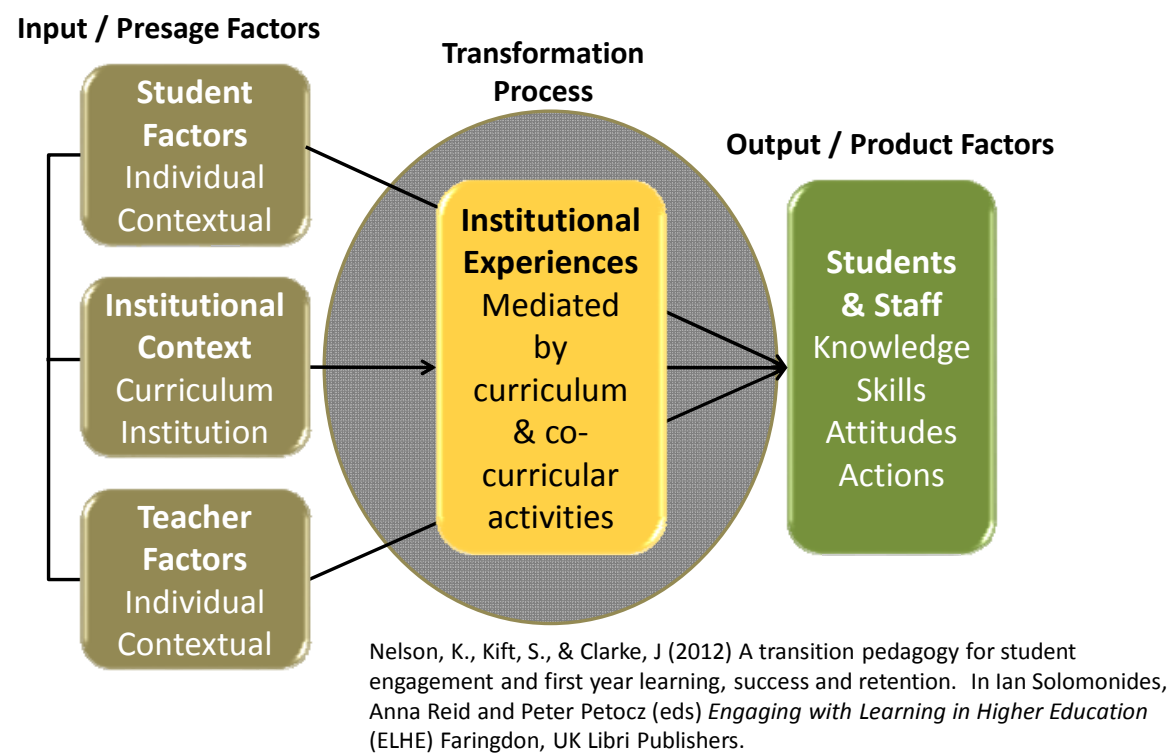

Figure 1: Individual and Institutional Characteristics Influencing Student Retention and Engagement (IICISRE) Model

I'd like to unpack the concept of engagement a little more.

Engagement has been described as both enigmatic and complex and Nick Zepke (2013) and Vincent Tinto (2013) in their experiences-the Individual and Institutional Characteristics Influencing Student Retention and Engagement (IICISRE) Model (pp. 121-122) shown in Figure 1 (Slide 59). However, a more sophisticated expression of student engagement has been recently provided by Ella Kahu (2013). I believe this model,

12 | The International J ournal of the First Year in Higher Education, 5(2) August, 2014 
which arises from a synthesis of other theoretical frameworks, has great utility as the foundation of a more sophisticated approach to enhancing the student experience. The framework has "six elements: the socio-cultural context; the structural and psycho-social influences; engagement; and the proximal and distal consequences" (p. 766) which are detailed in Figure 2 (slide 60).
The responsibility of institutions and students in contributing to engagement has been acknowledged for some time, however our current way of measuring engagement-such as through the Australasian Survey of Student Engagement (2008), which has been derived from the National Survey of Student Engagement (e.g., Kuh, 2007), and more recently the University Experience Survey (Department of Industry, Innovation, Science, Research

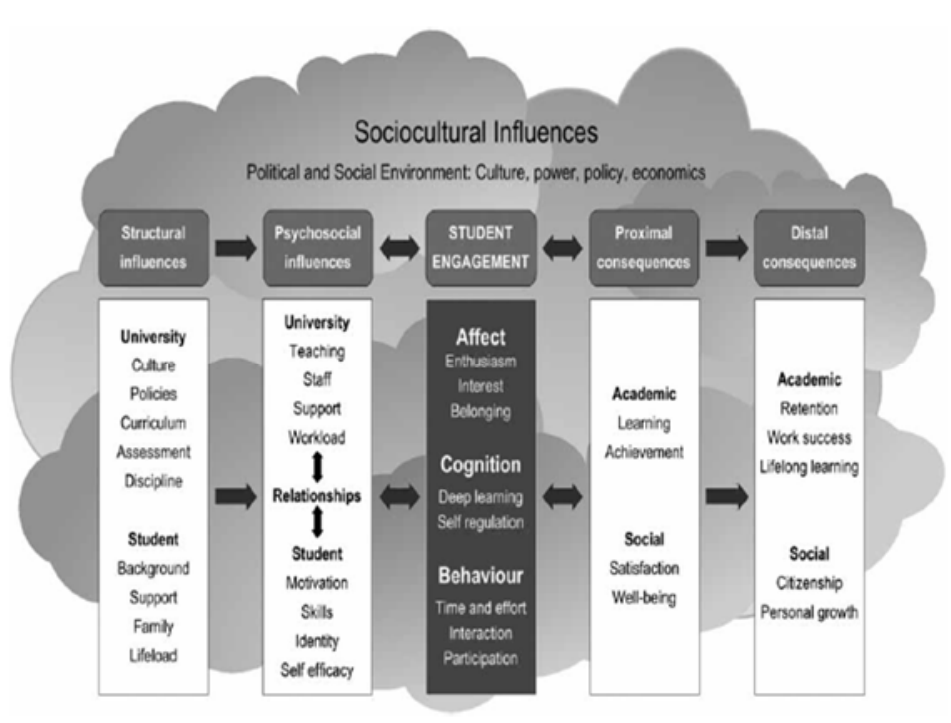

Figure 2: Kahu (2013) Conceptual framework of engagement, antecedents and consequences

The Kahu and IICISRE models share some characteristics, although these are better articulated by Kahu. Both models understand that engagement is multifaceted, is influenced by a range of factors some of which are more readily able to be controlled or altered than others and that there are consequences of engagement. Engagement leads to achievement, including learning enrichment, which in turn leads to retention at university and success in the work environment. and Tertiary Education, n.d.)-focus only on the collection of self-reported data about students' experiences. Further, as useful as the generational approach has been to describe the evolution of FYE practices (Kift et al. (2010)), it is just that, a tool for describing the past.

What is needed is a way to utilise the evidence base about which practices work and to attend to the institutional practices that are essential for maximising student engagement. To achieve this, with my 
colleagues in an OLT-funded project, 63 practices believed or shown to be critical for student engagement, were identified from empirical work with practitioners and from the literature.. Drawing on the work of Stephen Marshall and the schema he developed for the e-Learning Maturity Model (Marshall, 2010), we have articulated the student engagement, retention and success (SESR) practices for five dimensions of the institutional hierarchy and we have called the resulting framework the Student Engagement, Retention and Success Maturity model (SESR-MM) (Nelson, Clarke, Stoodley, \& Creagh, in press). This framework has been shown to have potential for understanding the institutional side of the equation by specifying the practices that are essential for student engagement. The major outcome of this work was that the SESR-MM has the potential for identifying key SESR practices and managing their development and ongoing refinement.

\section{Conclusion}

In concluding, I contend that we already have a broader foundation for enhancing the student experience in HE. We need to build on and harness the knowledge generated by nearly 20 years of attention to the FYHE in Australasia. To do that, I argue that we need to attend to Kahu's theoretical model and use the SESR-MM to manage and improve institutional practices.

To realise and deliver on the transformational promise of $\mathrm{HE}$ for individuals, families, and communities, and to truly engender a love for learning and a passion for intellectual discovery for all students, we will need to:

- Extend our thinking beyond first year experience to focus on the tertiary experiences of all students.
- Consider all types of transitionsinto tertiary learning, into developing an identity as student and future self, and out of learning into the world of work.

- Focus our attention on student achievement rather than our challenges.

- Aim to talk about retention as an outcome of engagement rather than concern ourselves with attrition data (however concerning).

- Think about success rather than problems ...

I propose we regroup with renewed energy and with a new broader scope for our research and practice - and that we use as our theme for the future Students Transitions Achievement Retention and Success (STARS). The future is in our hands.

\section{References}

Australasian Survey of Student Engagement. (2008) Attracting, engaging and retaining: New conversations about learning. Australasian Student Engagement Report. Melbourne, Australia: Australian Council for Educational Research

Australian Government. (2014). Portfolio budget statements 2014-15. Budget related paper no. 15 Education portfolio. Canberra, Australia: Author. Retrieved from https://docs.education.gov.au/node/35761

Bexley, E., Daroesman, S., Arkoudis, S., \& James, R. (2013). University student finances in 2012. A study of the financial circumstances of domestic and international students in Australia's universities. A report prepared for Universities Australia by the Centre for the Study of Higher Education, University of Melbourne. Canberra: Universities Australia.

Biggs, J. (1999). Teaching for quality at university. Buckingham, UK: Open University Press.

14 | The International J ournal of the First Year in Higher Education, 5(2) August, 2014 
Bowles, A., Fisher, R., McPhail, R., Rosenstreich, D., \& Dobson, A. (2014). Staying the distance: Students' perceptions of enablers of transition to higher education. Higher Education Research \& Development, 33(2), 212-225. doi: $10.1080 / 07294360.2013 .832157$

Bradley, D., Noonan, P., Nugent, H., \& Scales, B. (2008). Review of Australian higher education. Final report. Canberra, Australia: Commonwealth of Australia.

Brinkworth, R., McCann, B., King, S., Burke da Silva, K., Luzeckyj, A., Scutter, S., Palmer, E., Hill, J., Wright, V., \& McCann, J. (2013). Student and staff expectations and experiences: Final report. Prepared for the Office for Learning and Teaching. Sydney, Australia: Office for Learning and Teaching. Retrieved from http://fyhe.com.au/expectations/

Carlson, G., Scarbrough, J., \& Carlson, J. (2009). Holistic intervention program for at-risk students. In D. Nutt \& D. Calderon (Eds.), International perspectives on the first year experience in higher education (pp. 67-73). Columbia, NC: University of South Carolina.

Coughlan, S. (2010, September 21). Fee rise 'will not stop demand for university places.' $B B C$ News, Education and Family. Retrieved from http://www.bbc.co.uk/news/education$\underline{11373077}$

Crehan, M. (2014, June). Bridging the gap: Researching and enacting transition pedagogy for STEM and medical students. Seminar presented as part of the Seminar Series for 2014 under the auspices of the National Forum for the Enhancement of Teaching and Learning, Higher Education Forum, Dublin, Ireland.

Department of Industry, Innovation, Science, Research and Tertiary Education. (n.d.). The University Experience Survey. Advancing quality in higher education information sheet. Retrieved from http://www.innovation.gov.au/Search/pages/r esults.aspx?k=University $\% 20$ Experience $\% 20 \mathrm{Su}$ rvey

Devlin, M. (2011). Bridging socio-cultural incongruity: conceptualising the success of students from low socio-economic status backgrounds in Australian higher education. Studies in Higher Education, 38(6), 939-949. doi: $10.1080 / 03075079.2011 .613991$

Edith Cowan University. (n.d.). Fact sheet: First year experience. Joondalup, Australia: Author. Retrieved from intranet.ecu.edu.au/_data/assets/word_doc/0 003/491934/Fact-Sheet-FYE.doc
Flinders University. (2013). First year curriculum design and the transition pedagogy. Centre for University Teaching FACTSHEET. Adelaide, Australia: Author. Retrieved from http://www.flinders.edu.au/Teaching and Lear ning Files/Documents/CUT\%20Factsheet $\% 20$ Kifts\%20principles\%20of\%20curriculum $\% 20 \mathrm{~d}$ esign.pdf

Gale, T., \& Parker, S. (2011). Good Practice Report: Student transition into higher education. A report prepared for the Australian Learning and Teaching Council, Canberra, Australia: Department of Education, Employment and Workplace Relations. Retrieved from http://olt.gov.au/resource-library/goodpractice-reports

Gale, T., \& Parker, S. (2014). Navigating change: A typology of student transitions in Australian higher education. Studies in Higher Education 39(5), 734-753.

Greber, J. (2014, June 27). Joseph Stiglitz tells Tony Abbot to spend more. Financial Review. Retrieved from http://www.afr.com/p/national/joseph stiglitz tells tony abbott C3iphmUSBkpGLT]i21IxqI

Greller, W., \& Drachsler, H. (2012). Translating learning into numbers: A generic framework for learning analytics. Educational Technology and Society, 15(3), 42-57. doi: 10.1080/03075079.2012.721351

Herrick, C. (2011, March 17). New England automates student support. Computerworld. Retrieved from http://www.computerworld.com.au/article/38 $\underline{0115 / \text { new england automates student support }}$ L

Hurst, D. (2014, May 16). Massive uni fees: Higher interest rate will hit poorer students, Greens say. The Guardian. Retrieved from http://www.theguardian.com/world/2014/ma $\mathrm{y} / 16 /$ massive-uni-fees-coalition-adviser-saysfears-over-degree-costs-are-exaggerated

Kahu, E. (2013). Framing student engagement. Studies in Higher Education, 38(5), 758-773.

Kift, S. (2009). Articulating a transition pedagogy to scaffold and to enhance the first year student learning experience in Australian higher education. Final report for ALTC Senior Fellowship Program. Sydney, Australia: Australian Learning and Teaching Council. Retrieved from: http://www.olt.gov.au/resource-first-yearlearning-experience-kift-2009

Kift, S. \& Nelson, K. (2005). Beyond curriculum reform: embedding the transition experience. In Brew, A. 
\& Asmar, C. (Eds.) HERDSA 2005, 3-6 July, 2005, The University of Sydney, Sydney, Australia.

Kift, S., Nelson, K, \& Clarke, J. (2010). Transition pedagogy: A third generation approach to FYEa case study of policy and practice for the higher education sector. The International Journal of the First Year in Higher Education, 1(1), 1-20. doi: 10.5204/intjfyhe.v1i1.13

Krause, K-L., Hartley, R., James, R., \& McInnis, C. (2005). The first year experience in Australian universities: Findings from a decade of national studies. Melbourne, Australia: Centre for the Study of Higher Education, University of Melbourne.

Kuh, G. (2007, July). What matters to student success in the first year of university? Keynote address presented at the $10^{\text {th }}$ Pacific Rim First Year in Higher Education Conference, Brisbane, Australia. Retrieved from http://www.fyhe.com.au/past papers/papers0 7/fullprogram2.html

Lizzio, R. (2006). Designing an orientation and transition strategy for commencing students. A conceptual summary of research and practice. First Year Experience Project, Griffith University. Brisbane, Australia. Retrieved from http://www.griffith.edu.au/ data/assets/pdf f ile/0008/51875/Alfs-5-Senors-Paper-FYEProject,-2006.pdf

Lizzio, A., \& Wilson, K. (2004). First-year students' perceptions of capability. Studies in Higher Education, 29(1), 109-128. doi $10.1080 / 1234567032000164903$

Lizzio, A., \& Wilson, K. (2010, March). Assessment in first-year: Beliefs, practices and systems. Paper presented at the ATN National Assessment Conference, Sydney, Australia.

Marshall, S. (2010). A quality framework for continuous improvement of e-Learning: The eLearning Maturity Model. Journal of Distance Education, 24(1), 143-166.

Nelson, K., \& Clarke, J. (2014). The first year experience: looking back to inform the future. HERDSA Review of Higher Education, 1, 23-46. Retrieved from http://www.herdsa.org.au/wpcontent/uploads/HERDSARHE2014v01p23.pdf

Nelson, K., Clarke, J., Kift, S., \& Creagh, T. (2011). Trends in policies, programs and practices in the Australasian First Year Experience literature 2000-2010. The First Year in Higher Education Research Series on Evidence-based Practice. No. 1. Brisbane, Australia: Queensland University of Technology.
Nelson, K., Clarke, J., Stoodley, I., \& Creagh, T. (in press). Using a maturity model to build on the generational approach to student engagement practices. Higher Education Research and Development.

Nelson, K. \& Creagh, T. (2013). A good practice guide: Safeguarding student learning engagement. Brisbane, Australia: Queensland University of Technology. Retrieved from https://safeguardingstudentlearning.net/?page $\underline{\text { id }=62}$

Nelson, K., Duncan, M., \& Clarke, J. (2009). Student success: The identification and support of first year university students at risk of attrition. Studies in Learning, Evaluation, Innovation and Development, 6(1), 1-15.

Nelson, K., Kift, S., \& Clarke, J. (2012). A transition pedagogy for student engagement and first-year learning, success and retention. In I. Solomonides, A. Reid, \& P. Petocz, (Eds.), Engaging with learning in higher education (pp. 117-144). Oxfordshire, UK: Libri Publishing.

Nelson, K., Quinn, C., Marrington, A., \& Clarke, J. (2012). Good practice for enhancing the engagement and success of commencing students. Higher Education, 63(1), 83-96. doi: 10.1007/s10734011-9426-y

Nelson, K., Smith, J., \& Clarke, J. (2012). Enhancing the transition of commencing students into university: An institution-wide approach. Higher Education Research \& Development, 31(2), 185199. doi: $10.1080 / 07294360.2011 .556108$

Norton, A. (2013). Keep the caps off! Student access and choice in higher education. Melbourne, Australia: Grattan Institute. Retrieved from http://grattan.edu.au/report/keep-the-capsoff/

Organisation for Economic Cooperation and Development. (2013). Education at a glance2013: OECD Indicators. Paris, France: OECD Publishing. Retrieved from http://www.oecd.org/edu/eag2013\%20\%28en g\%29--FINAL\%2020\%20June\%202013.pdf

Pitman, T., Phillimore, J., \& Koshy, P. (2014, May 29). Retraction and corrected modelling on student fees and debt. The Conversation. Retrieved from http://theconversation.com/retraction-andcorrected-modelling-on-student-fees-and-debt$\underline{27339}$

Powell, S., \& MacNeil, S. (2012). Institutional readiness for analytics. A briefing paper. CETIS Analytics Series. JISC CETIS. Retrieved from http://publications.cetis.ac.uk/wpcontent/uploads/2012/12/InstitutionalReadiness-for-Analytics-Vol1-No8.pdf

16 | The International J ournal of the First Year in Higher Education, 5(2) August, 2014 
Pyne, C. (2014, May 13). More opportunity and competition in higher education. Media release. Ministers' media centre. Retrieved from http://ministers.education.gov.au/pyne/moreopportunity-and-competition-higher-education

RMIT University. (n.d.). The student lifecycle model. Transition in Transition out: Peer mentoring for sustainable development. Melbourne, Australia: Author. Retrieved from http://emedia.rmit.edu.au/tito/content/studen t-lifecycle-model

Scott, G. (2006). Accessing the student voice: Using CEQuery to identify what retain studentsand promotes engagement in productive learning in Australian higher education. Canberra, Australia: Department of Education, Science and Training.

Stiglitz, J. (2014). Crawford school oration 2014 - Crisis averted? Lessons from the global crisis. Retrieved from

http://www.youtube.com/watch?v=00favMuC KDg\&feature=youtu.be

Tinto, V. (2008). Access without support is not opportunity. Inside Higher Ed, June. Retrieved from

http://www.insidehighered.com/views/2008/ $\underline{06 / 09 / \text { tinto }}$

Tinto, V. (2013, July). Keynote address presented at the 16th International First Year in Higher Education conference, Wellington, New Zealand. Universities Australia.

Tinto, V. (2012). Completing college: Rethinking institutional action. Chicago, IL: The University of Chicago Press.

Tinto, V. \& Pusser, B. (2006). Moving from Theory to action: Building a model of institutional action for student success. In L. ... (Ed.), Reconceptualising success for underserved students in higher education (pp. 10-12). Iowa State University: National Postsecondary Education Cooperative. Retrieved from http://nces.ed.gov/npec/pdf/resp Rendon.pdf

Universities Australia. (2013). An agenda for Australian higher education 2013-2016: A smarter Australia. https://www.universitiesaustralia.edu.au/new s/policy-papers/Universities-Australia-PolicyStatement-2013---2016\#.U70uXihYV8E

University of Technology Sydney. (2014). 2014 guidelines: First year experience (FYE) grants: Embedding transition pedagogies in the curriculum. Widening participation retention and success: First year experience grants. Sydney, Australia: Author. Retrieved from http://www.iml.uts.edu.au/pdfs/FYE_grants_2 $\underline{014}$ guidelines updated2.pdf;
Victoria University. (2012). The VU agenda and blueprint for curriculum reform. Capabilities for the future. Melbourne, Australia: Author. Retrieved

from http://www.vu.edu.au/sites/default/files/wfg/ pdfs/VUAgenda-CurriculumBlueprintNov2012.pdf

Yorke, M. \& Longden, B. (2008). The first-year experience of higher education in the UK. Final report of a project funded by the Higher Education Academy. York, UK: Higher Education Academy. Retrieved from http://www.heacademy.ac.uk/news/detail/fye final report

Zepke, N. (2013). Student engagement: A complex business supporting the first year experience in tertiary education. The International Journal of The First Year In Higher Education, 4(2), 1-14. doi:10.5204/intjfyhe.v4i2.183

Zepke, N. \& Leach, L. (2010). Improving student engagement in post-compulsory education: $A$ synthesis of research literature. A report prepared for Teaching and Learning Research Initiative, Wellington, New Zealand. Retrieved July 4, 2011, from http://www.tlri.org.nz/assets/A ProjectPDFs/9261-Zepke/9261-Literature-review.pdf

Zepke, N., Leach, L., Prebble, T., Campbell, A., Coltman, D., Dewart, B., Gibson, M., Henderson, J., Leadbeater, J., Purnell, S., Rowan, L., Solomon, N., \& Wilson, S. (2005). Improving tertiary student outcomes in the first year of study. A report prepared for Teaching and Learning Research Initiative, Wellington, New Zealand. Retrieved from http://www.tlri.org.nz/improvingtertiary-student-outcomes-their-first-yearstudy 

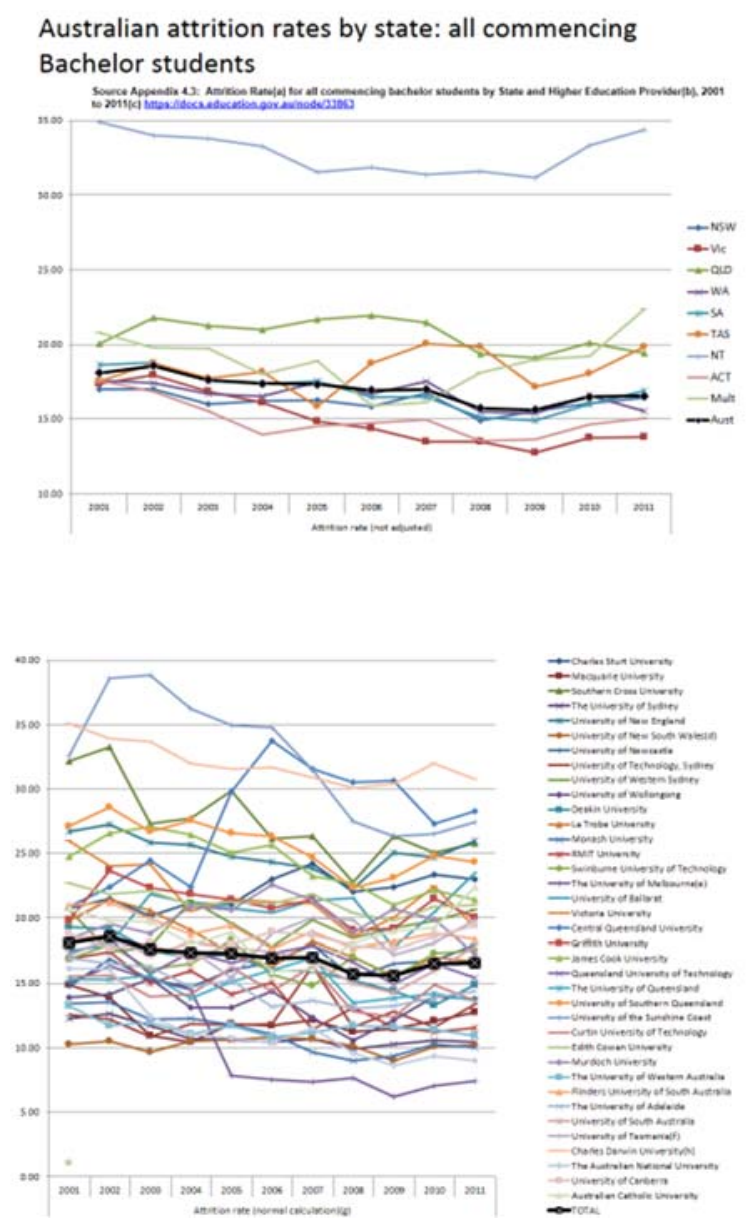

Slide 8

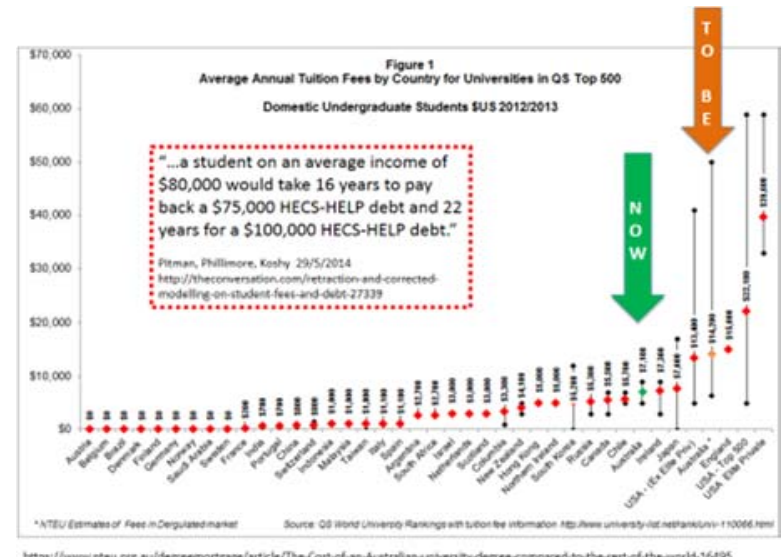

Slide 9

18 | The International J ournal of the First Year in Higher Education, 5(2) August, 2014 


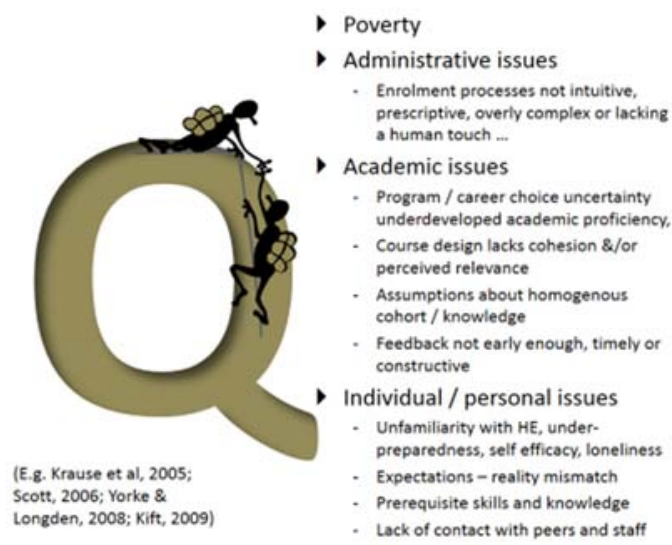

\section{... and students perceptions}

- Study - Skills, time mgt, help seeking, guidance - particularly from academic staff

- Effort - Motivation, commitment, working hard, joining-in, interactions with others

- Orientation - Usefulness as a precursor to study, effectiveness in meeting staff and introducing student services

- Learning@Uni - Accessibility of LMS and self-serve portals

- Culture - Feelings of belonging, value of being a student at uni

- Facilities - Infrastucture (incl: parking), computer labs, study areas, wireless network

- Social - Importance of regular, visible uni-led social events for friendships \& networking

\section{4-2007 - $1^{\text {st }} \& 2^{\text {nd }}$ Generation}

\begin{tabular}{|l|l|}
\hline $\begin{array}{l}\text { Still essentially subject, } \\
\text { program or faculty focus }\end{array}$ & $\begin{array}{l}\text { Principles of Design, } \\
\text { Engagement and } \\
\text { First gen still prevalent } \\
\text { but subtly more } \\
\text { sophisticated }\end{array}$ \\
\begin{tabular}{|l|l|} 
Assessment \\
Second generation \\
dominant - student \\
centred philosophy
\end{tabular} & $\begin{array}{l}\text { Evidence of cross- } \\
\text { institution collaboration } \\
\text { (academic and } \\
\text { professional staff) } \\
\text { - Many programs } \\
\text { 'tentative' } \\
2005-\text { Transition } \\
\text { Pedagogy (Kift \& Nelson) }\end{array}$ \\
\hline
\end{tabular}

Focus: Building expertise, capacity and knowledge through practice 


\section{Tinto: Conditions for Student Success}

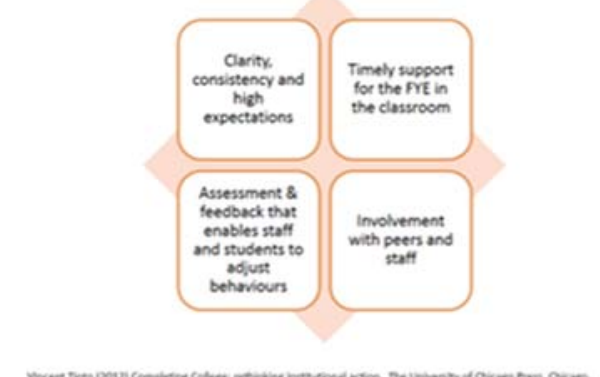

Lizzio \& Wilson (2010) Five senses of success
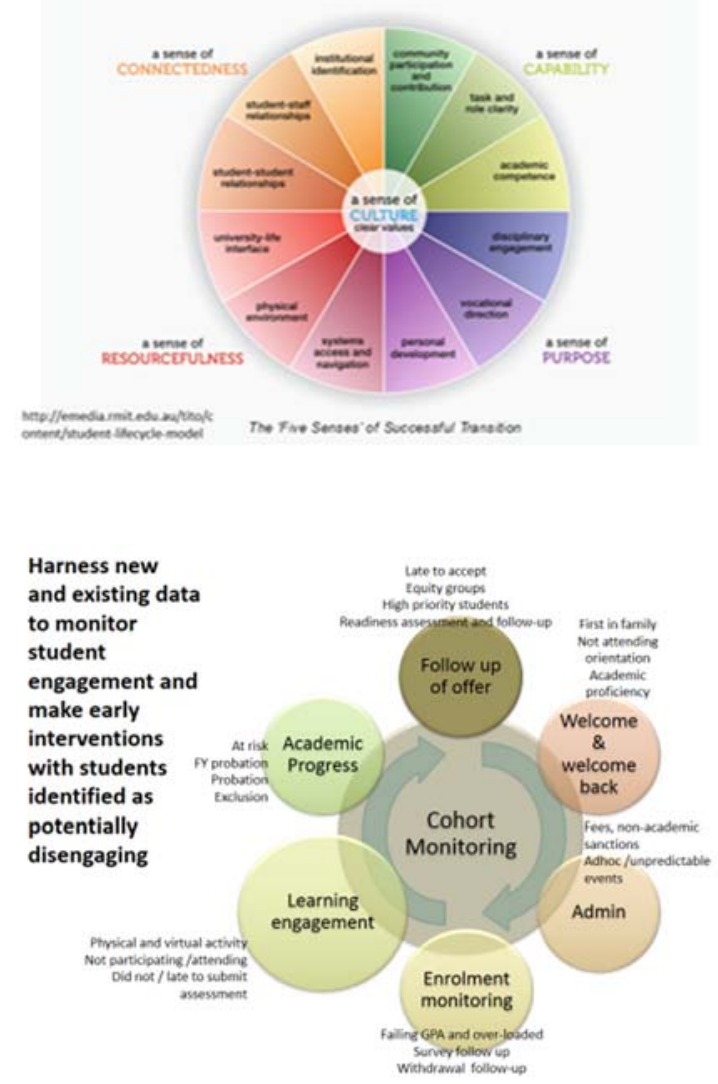

Slide 32

20 | The International J ournal of the First Year in Higher Education, 5(2) August, 2014 
The International J ournal of the First Year in Higher Education, 5(2) August, 2014 | 21 